\title{
PROSPECTS OF PINUS AND EUCALYPTUS PRODUCING COMPANIES IN THE STATE OF PARANÁ
}

\author{
Ailson Augusto Loper ${ }^{1}$; Vitor Afonso Hoeflich²; João Carlos Garzel L. da Silva ${ }^{3}$; Joésio Deoclécio Pierin \\ Siqueira $^{4}$; Alexandre Nascimento de Almeida ${ }^{5}$ \\ ${ }^{1}$ Federal University of Paraná, Rural Economy and Extension Department. Curitiba, Paraná, Brazil. ailsonloper@ufpr.br \\ ${ }^{2}$ Federal University of Paraná, Rural Economy and Extension Department. Curitiba, Paraná, Brazil. vitor.ufpr@ gmail.com \\ ${ }^{3}$ Federal University of Paraná, Rural Economy and Extension Department. Curitiba, Paraná, Brazil. garzelufpr@gmail.com \\ ${ }^{4}$ Federal University of Paraná, Retired Professor. Curitiba, Paraná, Brazil. joesio@ stcp.com.br \\ ${ }^{5}$ University of Brasilia, District, Brazil. alexalmeida@unb.br
}

Received for publication: 01/02/2019 - accepted for publication: 16/12/2020

\begin{abstract}
Resumo
Perspectivas das empresas produtoras de pinus e eucalipto no estado do Paraná. O objetivo deste trabalho foi analisar as perspectivas em relação à área plantada, produção florestal, intenção de investimentos e contratação de funcionários das empresas produtoras de pinus e eucalipto. A pesquisa teve como área de abrangência o estado do Paraná e como fonte de dados as empresas produtoras de matéria-prima florestal de origem plantada que atuam no estado, associadas à Associação Paranaense de Empresas de Base Florestal (APRE), a Organização das Cooperativas do Estado do Paraná (OCEPAR), o Sindicato das Indústrias de Papel e Celulose do Paraná (SINPACEL) e à Associação Brasileira da Indústria de Madeira Processada Mecanicamente (ABIMCI). A amostra é composta por 41 empresas, das 61 atuantes no estado, que responderam os questionários enviados por e-mail. Para a identificação das perspectivas das empresas foi solicitado o preenchimento de um quadro apontando uma porcentagem (0 à 100\%) que refletisse as projeções para os próximos 5 anos, período compreendido entre 2017 e 2021. A perspectivas relacionadas à área plantada, produção e investimentos, foram positivas, porém, a contratação de mão de obra pelas empresas integradas da indústria de celulose e papel apresenta uma perspectiva de redução. As Timberland Investment Management Organizations (TIMOS) formam o grupo que tem as expectativas mais positivas, sendo provavelmente responsáveis pela a expansão da área plantada, volume produzido, investimento e contratação de funcionários. Palavras-Chave: Perspectivas, Paraná, Empresas Florestais
\end{abstract}

\begin{abstract}
The objective of this work was to analyze the prospects for the next five years in relation to planted area, forest production, investment intention and hiring of employees. The research had as its area of coverage the state of Paraná and as a source of data, companies (legal entities) producers of forest raw material of planted origin that operate in the state. The contacts with the companies were obtained from the Paraná Association of Forest Based Companies (APRE), the Organization of Cooperatives of the State of Paraná (OCEPAR), SINPACEL and ABIMCI. The questionnaires were sent by e-mail to the entire contact base, aiming at the census. Thus, the resulting sample is made up of 41 companies, segmented between integrated and non-integrated companies, which corresponds to 17 and 24 companies. The evaluation answers were carried out. For the identification of the companies' prospects, it was requested to fill in a table indicating a percentage ( 0 to $100 \%)$ that reflects the projections for the next 5 years. The prospects related to the planted area, production and investments were positive, however, the panoramas related to hiring new employees by the pulp and paper industry (integrated companies) presents a prospect of reduction. The Timos are the group that has the most positive expectations, being responsible for the expansion of the planted area, volume produced, investment and hiring of employees. Keywords: Prospects, Paraná, Forest companies
\end{abstract}

\section{INTRODUCTION}

Brazilian forest plantations, started in the 20th century and driven by the 1966 Reforestation Tax Incentives Act (Law No. 5,106/66), have emerged as an economic option in regions where there are inappropriate land, climate or soil conditions. Since the beginning of the 21st century, the planted forest sector has been strongly consolidated in the country - for the most part - and promotes sustainable development in several regions (EISFELD; NASCIMENTO, 2015).

According to data from the Brazilian Tree Industry (IBÁ, 2015), the Brazilian planted tree sector is responsible for $91 \%$ of all wood produced for industrial purposes in the country, even though it occupies an area of only 7.8 million hectares, which corresponds to $0.9 \%$ of the national territory.

The forest-industrial complex brings together the various production chains that have their common link in forest production, as shown in Figure 1. Forestry production is responsible for supplying raw material to different industrial sectors, constituting an essential part of the production chain of several products, called forestbased products.

FLORESTA, Curitiba, PR, v. 51, n. 2, p. 303-310, abril/jun 2021.

Loper, A. A. et.al.

ISSN eletrônico 1982-4688

DOI: $10.5380 /$ rf.v51 i2. 64632 


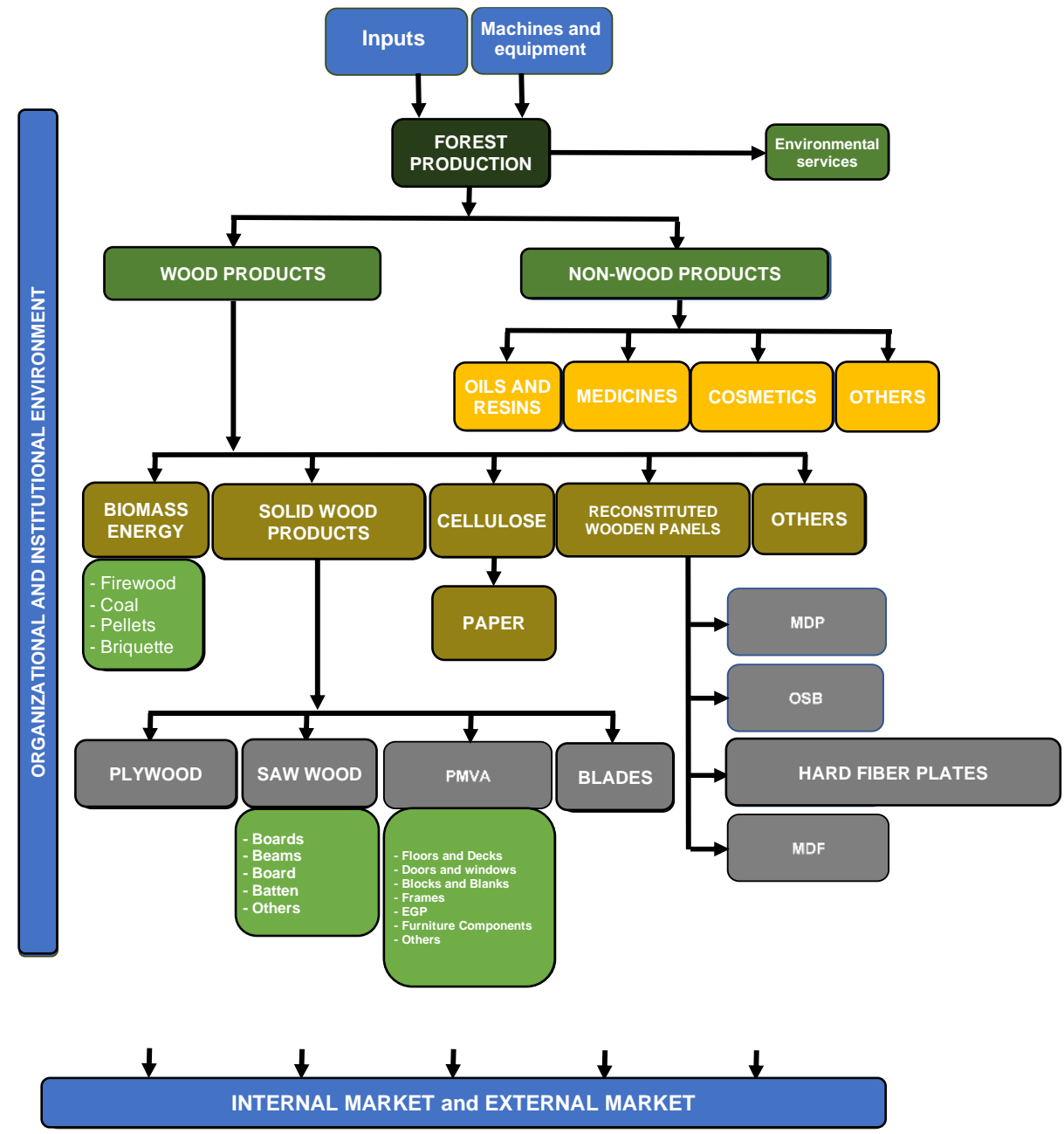

\section{SOURCE: THE AUTHOR (2017).}

Figure 1. Forest-industrial complex and simplified forest-based production chains.

Figura 1. Complexo florestal-industrial e cadeias produtivas de base florestal simplificadas.

The forest-based production chains bring together companies, investors and entrepreneurs who work in the supply of specific inputs and machines for the forestry activity, provision of support and specialized services, such as the production and planting of seedlings, harvesting of trees and transportation of wood, until the transformation of wood into intermediate and final goods, which interact in the organizational and institutional environment.

The wood cycle in Paraná, which started in the late 19th century, ended due to the almost depletion of native raw material, and the rise of coffee, at the end of the Second World War. Demands for forest products are now mostly met by planted forests. With a history of more than 50 years of experience with forest plantations, the market for products resulting from this activity in Paraná is consolidated and very diverse, involving the production of: firewood, charcoal, roundwood, sawn wood, cellulose, panels, among other wood-based products.

The forest planting areas in Paraná, in 2015, totaled 1,066,479 hectares (about 340 thousand hectares of eucalyptus, 653 thousand hectares of pine and 72 thousand hectares in clear cut), and the Center-South region accounts for the largest forest plantation area in the state (83.6\%) (EISFELD; NASCIMENTO, 2015). The production chains are important components for the sectorial and regional economic development. The economic growth of a region is associated with the performance of several production chains. In the specific case of Paraná, the industrial part based on forest raw materials was the basis for economic growth in several regions and, in several cities or regions; it is the main economic agent.

Due to the economic relevance of this industrial part, this article proposes to research in its main supplier, the companies operating in the pine and eucalyptus production segment in Paraná, identifying and measuring prospects in relation to planted area, production, investments and hiring employees, for a five-year planning horizon. 


\section{MATERIAL AND METHODS}

The research covered the state of Paraná, located in the southern region of Brazil. With an area of $199,307,945 \mathrm{~km}^{2}$ (20 million hectares), which corresponds to approximately $2.35 \%$ of the territory (SANTOS et al., 2004). In 2015, the state had a population of more than 11 million inhabitants, distributed in its 399 cities, resulting in a demographic density of 52.40 inhabitants $/ \mathrm{km}^{2}$ (INSTITUTO BRASILEIRO DE GEOGRAFIA E ESTATÍSTICA, 2015). According to the United Nations Development Program (UNDP), the Average Human Development Index (HDI) is 0.749.

Traditionally, logging in Paraná began in the early 20th century, based on the Araucária and Imbuia cut, representing, at the time, one of the state's main economic activities. However, the scarcity of native wood and the advent of the tax incentive law drove the beginning of forest planting in the mid-1960s. The initial objective of producing these forests was to replace the Araucária wood and supply the paper and cellulose sector. During this period, due to favorable edaphoclimatic conditions, plantations were concentrated in the genus Pinus, mainly in the species Pinus elliottii and Pinus taeda (EISFELD; NASCIMENTO, 2015).

The state of Paraná was chosen due to the current existence of an industrial complex based on consolidated and expressive planted forests (EISFELD; NASCIMENTO, 2015; SINDICATO DAS INDÚSTRIAS DE PAPEL, CELULOSE E PASTA DE MADEIRA PARA PAPEL, PAPELÃO E DE ARTEFATOS DE PAPEL E PAPELÃO DO ESTADO DO PARANÁ, 2014; INDÚSTRIA BRASILEIRA DE ÁRVORES, 2015).

\section{Sampling}

It was adopted as universe of this research companies (legal entities) that produce planted forest raw material that operate in the state of Paraná, and that are associated with some representative entity. The following entities were selected: The Paranaense Association of Forest Based Companies (APRE), Organization of the Cooperatives of the State of Paraná (OCEPAR), the Union of the Cellulose and Paper Industries of Paraná (SINPACEL) and the Brazilian Association of the Mechanically Processed Wood Industry (ABIMCI).

Based on the information received from these entities, duplicate properties were eliminated, generating a final list of 61 properties belonging to legal entities used in forest planting projects. This list formed the study population and all registered properties had specific data on location and contact.

This information allowed an initial telephone contact with all properties, followed by sending an e-mail with a questionnaire, in an attempt to perform a census. After the deadline for returning the questionnaires ended, 41 completed questionnaires were returned, which determined a sample for adherence of 41 cases, or $67 \%$ of the population.

The data collection period occurred between mid-September and the end of November 2016.

The companies surveyed have 655,979 hectares of forest plantations between their own and leased areas. In addition to the planted area managed by the companies, 44,150 hectares were established through forestry promotion.

\section{Procedures for data collection and validation}

The data used in this research are of primary and secondary nature, collected through the following research instruments: application of questionnaires and bibliographic research respectively.

The primary data were obtained through a structured and undisguised questionnaire ${ }^{1}$, with open, closed and multiple-choice questions, directed at companies and institutions operating in the planted forest production segment, which may or may not also operate in the first segments of industrialization of wood in the forest-based production chain in the state of Paraná.

The validation of the questionnaire was carried out through consultations with research professors at the Federal University of Paraná, directors of associations and directors of companies or units that produce forest raw material. Suggestions related to the units of measurement and the grouping or removal of variables were incorporated, creating a collection instrument compatible with the terms used in the area and the need for data for the research.

To identify the prospects of the companies, respondents were asked to fill in a table (Table 1) indicating a percentage ( 0 to $100 \%$ ) that reflected the prospect for the next five years related to the following aspects: planted area, forest production, investments and hiring employees.

\footnotetext{
${ }^{1}$ A structured research tool is one in which questions are presented in an organized manner and where all respondents answer the same question and in the same order. With this, the aim is to achieve a high standardization of questions, since all respondents answer exactly the same question.
}

FLORESTA, Curitiba, PR, v. 51, n. 2, p. 303-310, abril/jun 2021.

Loper, A. A. et.al.

ISSN eletrônico 1982-4688 
Tabela 1. Tabela utilizada para coleta das perspectivas.

Table 1. Table used for data collection.

\begin{tabular}{l|c|c|c}
\hline \multirow{2}{*}{\multicolumn{1}{c|}{ Aspects }} & \multicolumn{3}{|c}{ Possibilities in \% for the next five years } \\
\cline { 2 - 4 } & Reduce & Keep & Increase \\
\hline Planted area & $\%$ & $\%$ & $\%$ \\
\hline Production & $\%$ & $\%$ & $\%$ \\
\hline Investments & $\%$ & $\%$ & $\%$ \\
\hline Hiring employees & $\%$ & $\%$ & $\%$ \\
\hline
\end{tabular}

SOURCE: THE AUTHOR (2017).

After checking and checking the integrity of the data received, they were tabulated and transcribed to an Excel spreadsheet and then for processing in SPSS Statistics package version 13. For the analysis, statistical techniques appropriate to the nature of the data collected were used, using descriptive statistics, including frequency, percentages, tables and charts.

The percentages reported in the questionnaire for the planted area and production were applied directly, resulting in the quantification of the expected variations for the next five years in relation to the planted area and production, in absolute and relative terms and ordered according to the magnitude.

The investments and hiring of employees aspects were analyzed through the average of the percentages and the proportion of the companies that indicated to look for the tendencies of reducing, maintaining and increasing.

The stratification of companies was also carried out in order to identify a common profile in those that have the prospect of reducing, maintaining or increasing the planted area, production, investments and contracting in the coming years.

\section{RESULTS}

The sample was stratified primarily between integrated forest-based companies and non-integrated companies, with the stratification criteria of the company's operating environments in the production chain.

Table 2 shows the distribution of the sampled companies regarding the operating environment and the respective proportions.

Table 2. Operating environment of companies participating in the survey.

Tabela 2. Ambiente de atuação das empresas participantes da pesquisa.

NOT INTEGRATED

\begin{tabular}{c|c|c|c}
\hline Acronym & Capital structure & $\mathbf{n}$ & $\%$ \\
\hline NI & Independents & 19 & $79 \%$ \\
\hline NIT & Timo & 4 & $17 \%$ \\
\hline NIC & Cooperative & 1 & $4 \%$ \\
\hline \multicolumn{2}{r|}{ Total } & 24 & $100 \%$ \\
\hline
\end{tabular}

SOURCE: THE AUTHOR (2017).

\section{INTEGRATED}

\begin{tabular}{c|c|c|c}
\hline Acronym & Operation & $\mathbf{n}$ & $\mathbf{\%}$ \\
\hline ICP & $\begin{array}{c}\text { Cellulose and Paper } \\
\text { Industry }\end{array}$ & 6 & $35 \%$ \\
\hline IM & Timber Industry & 10 & $59 \%$ \\
\hline IE & $\begin{array}{c}\text { Integrated } \\
\text { Energy/Input }\end{array}$ & 1 & $6 \%$ \\
\hline \multicolumn{2}{r|}{ Total } & 17 & $100 \%$ \\
\hline
\end{tabular}

Among the non-integrated companies, it is possible to observe three distinct groups. The first group, called Non-Integrated (NI), comprises $79 \%$ of the companies classified as non-integrated and is formed by privately owned companies that operate only in the production of forest raw material and by companies that currently, produce and commercialize the production independently, but that at some point also industrialized the wood produced.

The second group is formed by foreign Timos, which represent $17 \%$ of the sampled non-integrated companies. Timos (Timberland Investment Management Organizations) are companies specializing in the management of forest assets that operate similarly to private equity companies, creating funds shared by multiple investors or exclusive funds for larger clients. This group was called Non-Integrated Timos (NIT).

The third group is formed by a forest cooperative, composed of 27 members, whose objective is to aggregate and organize forest producers in order, mainly, to increase the negotiating power in the purchase of inputs and in the commercialization of the produced wood and to reduce the costs through economies of scale. This group is called the Non-Integrated Cooperative (NIC).

FLORESTA, Curitiba, PR, v. 51, n. 2, p. 303-310, abril/jun 2021.

Loper, A. A. et.al.

ISSN eletrônico 1982-4688 
For a better analysis, the integrated companies were divided into three groups. The largest group, comprising $59 \%$ of the companies participating in the research, called Integrated Wood Industry (IM), is composed of vertical companies producing: reconstituted panels, plywood panels, packaging, sawn wood, PMVA (mainly moldings), structural wood, decorative cut veneers.

The second group included vertical companies producing: cellulose, high-yield pulp, paper and packaging and paper products. This group is called Integrated Cellulose and Paper (ICP) and makes up 35\% of the sample.

The third group consists of only one animal protein production company, which, through its forestry unit, produces forest biomass for use as an energy input in its production process and is called Integrated Energy (IE).

\section{Prospect identification}

The prospects regarding planted area and forest production were obtained by directly applying the percentages indicated on the volumes and planted areas informed by the companies, based on the end of the year 2017. In the case of investments and hiring of labor, the averages of the percentages reported were obtained.

Figure 2 summarizes the prospects identified by means of arrows that represent trends in maintenance, increase or decrease.

SOURCE: THE AUTHOR (2017).

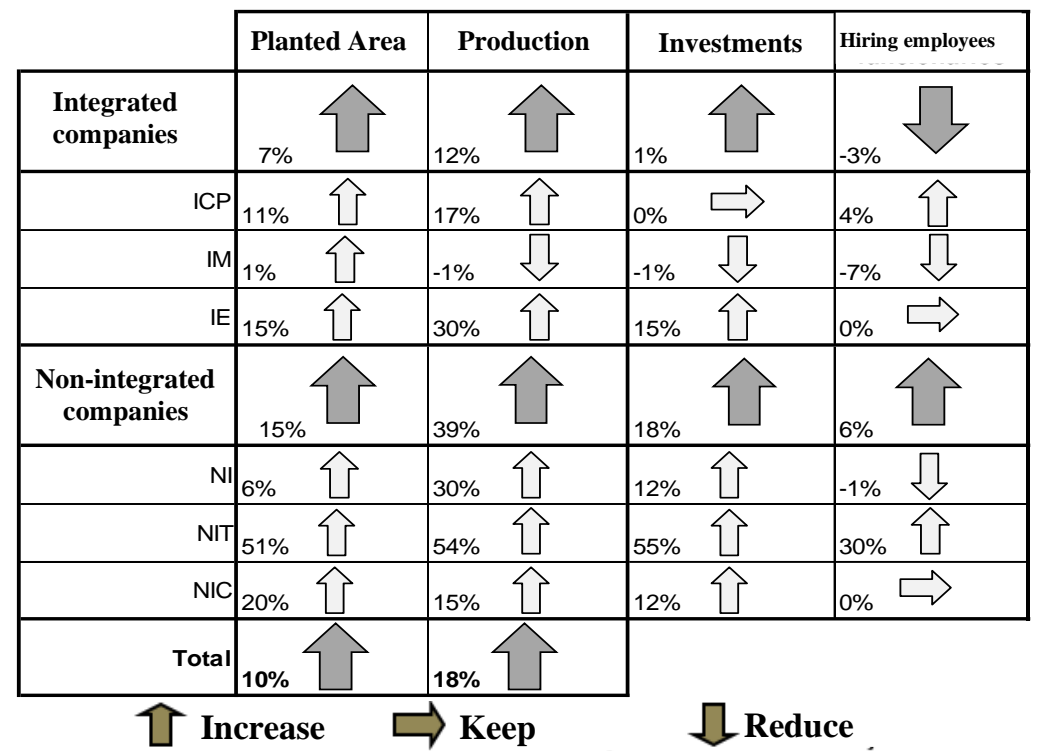

Figura 2. Perspectivas identificadas em cada ambiente de atuação das empresas.

Figure 2. Prospects identified in each business environment.

Analyzing the sample in general, 59\% of the companies informed that they will maintain the planted area and $38 \%$ that they intend to increase their areas. Only one company has the prospect of reducing its planted area. Table 3 summarizes the prospects in absolute numbers and variations of the planted area per segment.

Table 3. Net growth estimate of planted area for the next five years.

Tabela 3. Perspectivas em termos absolutos e suas variações em relação à área plantada para os próximos cinco anos

\begin{tabular}{|c|c|c|c|}
\hline Operating environment & $\begin{array}{c}\text { Current area } \\
\text { planted (ha) }\end{array}$ & $\begin{array}{c}\text { Planted area prospect } \\
\text { (ha) }\end{array}$ & Variation \\
\hline Integrated companies & 384,026 & 409,946 & $7 \%$ \\
\hline ICP & 211,284 & 235,479 & $11 \%$ \\
\hline $\mathrm{IM}$ & 168,120 & 169,152 & $1 \%$ \\
\hline IE & 4,622 & 5,315 & $15 \%$ \\
\hline Non-integrated companies & 281,952 & 322,877 & $15 \%$ \\
\hline NI & 220,938 & 232,488 & $6 \%$ \\
\hline NIT & 56,014 & 84,389 & $51 \%$ \\
\hline NIC & 5,000 & 6,000 & $20 \%$ \\
\hline Total & 665,979 & 732,822 & $10 \%$ \\
\hline
\end{tabular}


The analysis of planted areas informed by the companies made it possible to measure the size of the companies. Table 4 shows the classification of the size of the companies, the proportions of companies in each range and how much they represent in terms of planted area.

Table 4. Total planted area, planted area participation and market share in relation to company size. Tabela 4. Porte, respectivas proporções das empresas e participação em termos de área plantada.

\begin{tabular}{c|c|c|c}
\hline Size & Planted area (ha) & Companies & Planted area \\
\hline Very large & above 90,000 & $7 \%$ & $58 \%$ \\
\hline Large & from 10,000 to 25,000 & $29 \%$ & $28 \%$ \\
\hline Average & from 5,001 to 10,000 & $20 \%$ & $9 \%$ \\
\hline Small & up to 5,000 & $44 \%$ & $5 \%$ \\
\hline
\end{tabular}

SOURCE: THE AUTHOR (2017).

Regarding the production of wood, $50 \%$ of the sampled companies indicated a prospect of increase, $42 \%$ of maintenance and $8 \%$ of decrease in forest production in the coming years.

The prospect of an increase in production of about 3.5 million cubic meters is evidenced, which represents $18 \%$ increase in the volume produced in 2016 by the sampled companies. Integrated companies point to the prospect of an increase of $12 \%$, whereas non-integrated companies expect to increase their production by almost $40 \%$.

Table 5 presents the current production, the outlook and the changes in the volume produced by segment for the next five years.

Tabela 5. Perspectiva quanto ao volume produzido por segmento para os próximos cinco anos Table 5. Production estimate per segment for the next five years

\begin{tabular}{|c|c|c|c|}
\hline Operating environment & $\begin{array}{l}\text { Current production } \\
\qquad\left(\mathbf{m}^{3} / \mathbf{h a}\right)\end{array}$ & $\begin{array}{c}\text { Production } \\
\text { perspective }\left(\mathrm{m}^{3} / \mathrm{ha}\right)\end{array}$ & Variation \\
\hline Integrated companies & $15,887,331$ & $17,805,580$ & $12 \%$ \\
\hline ICP & $11,170,200$ & $13,063,400$ & $17 \%$ \\
\hline IM & $4,470,300$ & $4,421,300$ & $-1 \%$ \\
\hline IE & 246,831 & 320,880 & $30 \%$ \\
\hline Non-integrated companies & $4,271,720$ & $5,948,295$ & $39 \%$ \\
\hline NI & $2,366,720$ & $3,073,545$ & $30 \%$ \\
\hline NIT & $1,740,000$ & $2,685,000$ & $54 \%$ \\
\hline NIC & 165,000 & 189,750 & $15 \%$ \\
\hline Total & $20,159,051$ & $23,753,875$ & $18 \%$ \\
\hline
\end{tabular}

SOURCE: THE AUTHOR (2017).

Segmenting companies by size, it is identified that companies classified as medium are the only group that has the prospect of reducing their production (-8\%); while large companies indicated their intention to increase significantly, aiming to increase their production by 480 thousand cubic meters in the next five years, which corresponds to an increase of $72 \%$ in relation to 2016. Companies classified as very large and small expect to increase production by $14 \%$ and $10 \%$, respectively.

Analyzing the responses regarding investments, companies are divided between the prospects of maintenance and increase, respectively, $49 \%$ and $46 \%$. Only 5\% reported that they would reduce investments in the coming years, compared to 2016.

It appears that the outlook related to investments is quite heterogeneous, varying between a $25 \%$ reduction and a $125 \%$ increase, which on average results in an $11.5 \%$ increase prospect.

Considering the sample in a segmented way, it is clear that $46.2 \%$ of the integrated companies had the prospect of maintenance, $38.5 \%$ increase, and $15.4 \%$ have the prospect of reducing investments in the next five years. 
Non-integrated companies, on the other hand, are divided in a perfectly balanced way between maintenance and increased investment levels. No company that makes up this group has indicated the intention of reduction.

The prospects collected in relation to hiring employees are distributed as follows: $58 \%$ of companies intend to maintain, $25 \%$ intend to increase and $17 \%$ intend to reduce.

The average of the percentages established by the companies in relation to the hiring of employees for the next years was $2.9 \%$, representing, consequently, a prospect of increase of $2.9 \%$. The reported prospects ranged from a $60 \%$ reduction to a $100 \%$ increase, with an emphasis on a company in the NIC subgroup, which intends to double its hiring in the next five years.

\section{DISCUSSION}

Despite the majority tendency to maintain the planted area, the analyzes allowed to identify a prospect of an increase in plantations in the order of 66.8 thousand hectares in the next five years, which represents an increase of $10 \%$ in the sampled forest base; therefore, integrated and non-integrated companies point to an increase of $6.7 \%$ and $14.5 \%$ in their planted areas, respectively. The increase is mainly based on the prospects of non-integrated companies, which account for $61 \%$ (41 thousand hectares) of the increase projection. It is worth mentioning the NITs that have the prospect of increasing their planted areas by $51 \%$.

A significant portion of the planted area, about $86 \%$, is managed by $36 \%$ of the companies, which in absolute terms means that 15 companies sampled have about 570 thousand hectares of forest planting, demonstrating the high concentration of forest plantations in Paraná.

Although integrated companies have a prospect of variation in production approximately three times greater than integrated companies, the participation of integrated companies in the projected increase in volume is higher, 1.9 million cubic meters (53\%), against 1.6 million cubic meters (47\%) of non-integrated companies. This is due to the large volume produced by the integrated companies.

Relating the size of the companies and the investment prospects for the coming years, we highlight the companies classified as small and those classified as large because they present the greatest prospects, in relative terms. On average, small companies intend to increase their investments by $15 \%$ and large ones by $14 \%$. The very large and medium-sized companies indicated an average increase of $4 \%$ in their investments.

Unlike the patterns identified during the analysis of the prospects related to the planted area, production and investments, the hiring of employees presents a prospect of reduction, possibly reflecting the result of investments in production technologies.

The IM (Wood Industry - Indústria Madeireira) had the worst prospects, with emphasis on the projection of a 7\% drop in the contraction of employees; while the NIT (Timos) presented the best prospects among all strata of the sample, with increases in planted area, production and investments of more than 50\%, and 30\% in the hiring of labor for the next years. In this context, the NITs are configured as a force for expanding forest production in Paraná.

\section{CONCLUSIONS}

- The prospect in relation to the planted area was of a $10 \%$ growth. This same perception occurs in relation to forest production, with a prospect of an $18 \%$ increase in the period from 2017 to 2021 . It is noteworthy that this perception may have been influenced by the economic context of recession that the country was in during the period of data collection.

- Regarding the forest production in Paraná, it is concluded that for the 2017-2021 period, non-integrated companies would form the group that, proportionally, would have the largest increase in wood production.

- Based on the prospects reported for the 2017-2021 period (which considers: $1 \%$ increase in plantations, $1 \%$ reduction in production and maintenance of investments and hiring of employees); it can be concluded that the integrated companies of the solid wood and reconstituted panels industry would be the most affected by the national and international economic environment, presenting the most negative prospects in relation to the planted area, wood production, investments and hiring of employees. This group's main consumer market is the civil construction industry, a sector that has cycles strongly related to Brazil's unstable political and economic scenario.

- Timos form the group that has the most positive prospects, being the main responsible for the expansion of the activity in terms of planted area, volume produced, investment and hiring of employees.

FLORESTA, Curitiba, PR, v. 51, n. 2, p. 303-310, abril/jun 2021.

Loper, A. A. et.al.

ISSN eletrônico 1982-4688 
- Unlike the patterns identified during the analysis of the prospects related to the planted area, production and investments, which were positive, however, at very low intensities, the hiring of employees by the integrated companies in the pulp and paper industry presents a prospect of reduction.

\section{REFERENCES}

BRASIL. Ministério da Agricultura, Pecuária e Abastecimento. Cadeia produtiva de madeira. Secretaria de Política Agrícola, Instituto Interamericano de Cooperação para a Agricultura. BUAINAIN, Antonio Márcio; BATALHA, Mário Otávio. (Coord.). Brasília: IICA: MAPA/SPA, 2007. v. 6: Agronegócios. 84 p.

BRASIL. Lei $\mathrm{n}^{\circ}$ 5.106, de 02 de setembro de 1966. Dispõem sobre os incentivos fiscais concedidos a empreendimentos florestais. Available in: <https://presrepublica.jusbrasil.com.br/legislacao/103351/lei-510666>. Accessed: September 9, 2019.

EISFELD, R. de L.; NASCIMENTO, F. A. F. do. Mapeamento dos plantios florestais do Estado do Paraná. Curitiba: Instituto de Florestas do Paraná, 2015. 76 p.

INDÚSTRIA BRASILEIRA DE ÁRVORES (IBÁ). Anuário Estatístico IBÁ 2015. Brasília, 2015. 64 p.

INSTITUTO BRASILEIRO DE GEOGRAFIA E ESTATÍSTICA (IBGE). Anuário Estatístico Brasileiro. 2015. Available in: <http://www.ibge.gov.br/home/>. Accessed on: October 10, 2016.

SANTOS, M. M.; COELHO, G. M.; SANTOS, D. M.; FELLOW, L. F. Prospecção de tecnologias de futuro: métodos, técnicas e abordagens. Parcerias Estratégicas, n. 19, dez. 2004.

SINDICATO DAS INDÚSTRIAS DE PAPEL, CELULOSE E PASTA DE MADEIRA PARA PAPEL, PAPELÃO E DE ARTEFATOS DE PAPEL E PAPELÃO DO ESTADO DO PARANÁ (SINPACEL). Panorama Setorial 2013/2014. Curitiba, 2014. 64 p. 